\title{
Time is money: How landbanking constrains housing supply
}

\author{
Cameron K. Murray*
}

January 24, 2020

\begin{abstract}
Many housing policies aim to increase supply and reduce prices through rezoning, relying on the assumption that increasing allowable densities automatically accelerates the rate of housing supply. However, the existence of landbanking (land hoarding), where land able to be profitably developed for housing is withheld from the market in anticipation of future gains, undermines the logic of such policy changes.

We expose major limits of the static housing supply model behind these policies by looking at the degree to which landbanking behaviour is consistent with model predictions. To do this, we assemble a new dataset of home sales and landbanks from the annual reports of Australia's top eight publicly-listed residential developers from 2001 to 2018 and use complete state-level planning approvals and lot production data in Queensland, Australia.

In contrast to the static model prediction that landbanks serve the function of inventories, and are hence minimised, we find that (1) over 200,000 housing lots, or 13 years of new supply, are held by the eight largest housing development companies, and eight years of these landbanks are held in housing subdivisions that are approved and already for sale, that (2) the amount of zoned supply in a region is unrelated to the rate of new housing supply, and that (3) housing developers routinely delay housing production to capitalise on market cycles. Dynamic incentives to maximise total returns, including capital gains in the option value of undeveloped land, could be related to observed behaviour.
\end{abstract}

Keywords: Land banking, Land hoarding, Housing supply, Housing policy, Dynamics. JEL Codes: R14, R31, R52.

\footnotetext{
*Henry Halloran Trust, The University of Sydney, Camperdown NSW 2006. Email: c.murray@sydney.edu.au
} 


\section{Introduction}

Economic analysis of rapid housing price growth often leads to the conclusion that planning regulations are to blame, as they are thought to constrain the rate of new housing supply. ${ }^{1}$ This 'planning constrains supply' story has motivated policies aimed at reducing home prices by relaxing planning controls over the density, design and location of new housing. For example, Daley et al. (2017) argue that high home prices in New South Wales have arisen mainly "because of legislative restrictions on the effective supply of residential land - both limits on rezoning for urban infill and limits on developing land at the urban fringe." The New South Wales government has adopted this view of planning policy noting that "[n]ew tools for rezoning will... unblock housing and employment supply" (NSW Government, 2013), while the Australian government established a National Housing Supply Council (NHSC) in 2008 to focus on "planning and development approval arrangements" to solve a "deficiency in supply [that] has contributed to rising house prices" NHSC (2013).

But such policies never seem able to stop rapid home price growth, even in cities and countries widely claimed to have supply-friendly planning regulations (Costello \& Rowley, 2010; Gurran \& Phibbs, 2013; Gomez-Gonzalez et al. , 2018). For example, Houston, Texas, is widely known for its unrestrictive zoning and responsive supply yet home prices increased $49 \%$ from 2012 to 2018 (U.S. Federal Housing Finance Agency, 2019). After the 2000s home price boom some prominent urban economists noted that "the fact that highly elastic places had price booms is one of the strange facts about the recent price explosion" (Glaeser et al. , 2008).

We argue that such policy failures occur because they are based on static economic models of production that ignore important dynamic incentives governing the rate of new housing supply. This leaves few explanations for rapid price increases other than that 'planning constrains supply'. In static models, new housing is produced from land and construction inputs if its price exceeds input cost, or $p>l+c$, where $l$ is the price of the land input and $c$ is the total development cost. The equivalent condition in flow terms is $r_{H}>i(l+c)$, where $r_{H}$ is the net housing rent and $i$ is the interest rate. All potential homes where rents (or prices) satisfy this condition are produced instantly to ensure there are never inventories of profitable development sites. Subsequently, if prices (or rents) rise sufficiently for marginally unprofitable development locations to become profitable according to this supply condition, then these locations will also be immediately used for housing.

If the regulatory costs of new housing can be reduced, such as by lowering impact fees (reducing total costs of construction), or by relaxing density restrictions such as minimum lot sizes, or floor-area-ratio limits, that allow each dwelling to use less land (reducing land costs), additional profitable development options will be created and immediately taken up. Rezoning areas that were previously unavailable for housing also triggers immediate new supply by creating new locations that satisfy this supply condition. This is why planning controls are thought to be a powerful tool to combat rising home prices - they can create vast amounts of lower-cost housing supply because wherever they change this supply condition new housing will be immediately taken up to rapidly shift prices to a new lower equilibrium.

We provide evidence that this static model fails to represent the housing supply behaviour of private housing developers. Rather than build all profitable housing as soon as possible, housing developers hold a large inventory of land-their landbank. In a static model world,

\footnotetext{
${ }^{1}$ Such as Quigley \& Raphael (2004), Glaeser et al. (2005), Quigley \& Rosenthal (2005), Glaeser et al. (2008), Glaeser \& Ward (2009), Hsieh et al. (2012), Paciorek (2013), Gyourko \& Molloy (2015), Kendall \& Tulip (2018), Lees (2018), and Daley et al. (2019)
} 
these landbanks should not exist at all, or at the very least be minimised. Housing developers should only purchase sites where development is legal and profitable (in expectation), building immediately.

Our empirical evidence breaks open the housing production process to see whether landbanks have the economic function of an inventory, as static models assume, and are minimised. We find none of the expected patterns of the static model in the data. Instead, we find that (1) over 200,000 housing lots, or 13 years supply, are held in landbanks owned by just the eight largest housing development companies and eight years worth of landbanks are in subdivisions that have been approved and are already for sale, meaning planning regulations or delays cannot be the reason these large landbanks are held, that (2) the amount of zoned planned stock in a region is unrelated to the rate of new housing supply, and that (3) housing developers routinely delay housing production to capitalise on market cycles. These patterns are all inconsistent with the static housing production model and hint that timing housing production to match demand cycles is the main driver of production decisions.

While our objective is to disprove the value of the static model in understanding housing supply behaviour, we also offer ideas about how incorporating dynamic economic considerations, consistent with the real options and capital budgeting approaches to investment, can account for the high degree of observed landbanking. In a dynamic modelling approach, if the increase in the value of land is of equal significance in the profit function to income from converting land into housing, then the value change of the perpetual real option (but not obligation) to develop undeveloped land is cost of development that needs to be considered. Doing so substantially changes the hurdle condition for new housing supply compared to the static model.

We proceed by first reviewing the relevant literature and historical context for the dominance of the static modelling approach to housing supply, before review the data, methods, and theory that inform our analysis. We then present the results of our analysis, and discuss how a dynamic approach might be a fruitful direction in housing supply modelling, before concluding.

\section{Literature}

The microeconomic determinants of housing supply are not well understood, but for a long time the academic literature supported the view that housing supply was perfectly elastic at any price (Muth, 1960; Follain, 1979; Stover, 1986; DiPasquale, 1999). The real options literature helped shed light on the micro-economics of housing supply by incorporating the idea the conversion of land into housing is not a short-run supply decision but an irreversible long-run capital allocation decision resembling a perpetual option.(Shoup, 1970; Markusen \& Scheffman, 1978; Titman, 1985; Williams, 1991; Capozza \& Li, 1994). Therefore both the timing and intensity of development are choice variables in housing development.

However, the research focus on timing decisions fell away during the 2000s global home price boom when new metrics of the stringency of town planning regulations were shown to correlate with higher home prices. ${ }^{2}$ This led to a shift away from real options models towards static economic models where planning regulations appeared to be the primary determinant of the rate of new housing supply and therefore prices (Glaeser \& Gyourko, 2003; Paciorek, 2013; Glaeser \& Gyourko, 2018). This shifting focus in the literature is illustrated in Table A1 of Appendix

\footnotetext{
${ }^{2} \mathrm{~A}$ relationship between prices and metrics of planning regulations are also not by themselves evidence in favour of policies that removing planning controls, as high value cities and suburbs are more likely to implement detailed planning controls to preserve their high levels of amenity (Quigley \& Rosenthal, 2005; Davidoff, 2016).
} 
A, which shows word-counts and cross-citations of a sample of the real options and regulationfocussed literature. While real options analysis has a primary focus on density, timing, and delay, the new regulation literature has a focus on supply, elasticity, and regulation, without reference to the real options literature.

The regulation-focussed literature is notable for its lack of attention to either its theoretical consistency or its focus on the design and implementation of regulations themselves (Gurran \& Phibbs, 2015; Murray, 2019). But the most glaring challenge to the static models of the regulation-focussed view is the existence of landbanking, where housing developers "deliberately distort the market by limiting supply" (COAG, 2012, p.25). While landbanking is relatively unstudied in the academic literature (White, 1986; Zhang et al. , 2015; Huang et al. , 2015), multiple government reviews into housing supply in the United Kingdom (Barker, 2005; Callcutt et al. , 2007; Letwin, 2018) found that new housing developers will not rapidly increase development even if planning rules allow them to. The most recent review noted that the fundamental determinant for the rate of new housing supply was the absorption rate, or the "value-unaffecting rate of sale" (Letwin, 2018, p.14). This means that owners of large development sites prefer to hold land undeveloped in their landbank rather than build new homes at a rate that would depress prices, affecting future returns, even if those prices exceed their input costs.

Much of the existing analysis of landbanking and housing supply is incidental to the study of other planning issues. For example, Woodcock et al. (2011) look at why Melbourne's planning policy to promote density rather than sprawl seems to have failed. After tracking all planning applications, approvals, and construction over a seven year period in a case study infill area, they find that many infill developments are voluntarily delayed, as "developers anticipate that the planning system will ultimately approve significant increases in height and density". They note that approvals already gained, but undeveloped, "produce significant capital gains that can be cashed without construction." The returns to undeveloped land were also highlighted by Kania (2014) who noted that "the costs related to owning a land bank decreased as a result of the fast growth in the market value of the land", hence reducing the urgency to develop. Using a neat case study in Perth, Costello \& Rowley (2010) concluded that the new supply and home price evidence showed that " $[\mathrm{r}$ ] eleasing large quantities of land in an area does not automatically increase housing affordability." A thorough empirical analysis of landbanking may help move the housing supply research agenda beyond static models.

\section{Data and Methods}

\subsection{Modelling housing production}

Figure 1 characterises the housing planning and production process in terms of stocks and flows, allowing static model predictions to be related to observed landbanking behaviour. Planned stock is the total amount of new housing that can be built within current planning regulations (such as zoning) and economic conditions (i.e. where the static supply condition is satisfied). It exists as two stocks in the housing production process - either in the approved stock that is not yet developed but has the necessary planning approvals to be developed, or as residual planned stock, which is able to be developed into housing according to planning regulations but is currently not approved to be.

Planned stock can be increased through planning and upzoning decisions, or reductions in fees associated with housing development, which create additional locations where new housing can 
be profitably developed and is shown here as a flow into the residual planned stock. ${ }^{3}$ The residual planned stock flows into the approved stock when planning applications to develop a site are made by landowners and approved by the relevant regulatory agency. The approved stock flows into the existing housing stock when a developer/landowner with an approved housing development constructs the housing, which is typically triggered by a sale. ${ }^{4}$ Changes in stocks at each point in the process arise from the net flows into them.

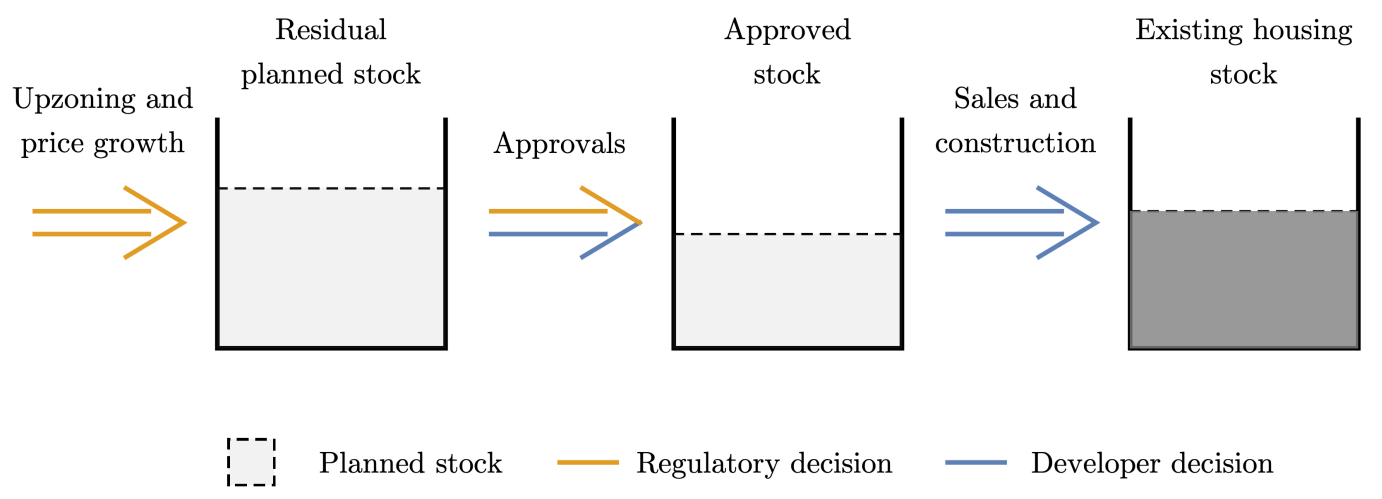

Figure 1: Flows and stocks of housing production stages

In this system, regulatory agencies make two choices (marked as orange arrows in Figure 1). Along with price changes, they determine the flows into the residual planned stock with zoning decisions and policies about fees on new development. They also decide whether to approve or deny planning applications made by housing developers, which jointly determines the flow into the approved stock. This flow is the rate of planning applications in term of dwelling units multiplied by the rate they are approved (this joint decision is marked as an orange and blue arrow in Figure 1). As well as deciding when and if they make a planning application, housing developers decide when and if they sell and construct approved housing. As long as there is a positive approved stock, it is this final private decision of housing developers that determines the rate at which the existing housing stock increases (blue arrow in Figure 1).

Information about the stocks and flow in the housing production process can be used to test the validity of the static economic model of housing supply. Recall, that when the hurdle condition for new housing, $p>l+c$, is met, the model assumption is that private developers will accelerate housing supply, immediately bringing to market all profitable housing subdivisions. In short, the static model collapses any notion of voluntary choices over the timing of private developer decisions (blue arrows in Figure 1). In the equilibrium, all profitable opportunities have been taken up. The implication is that private developers will minimise their holdings of costly inventories of planned stock, and specifically of approved stock, due to the speed of their sales decisions that push them to the equilibrium. The is a testable prediction.

Further, any additions to the planned stock from planning changes will correlate with the rate of new housing supply. A reduction in the required land input per dwelling will create new profitable development sites, which will flow rapidly through this production process to the existing housing stock, with inventories held only as briefly as necessary, and sales rates maximised. Another

\footnotetext{
${ }^{3}$ Or decreased by additional restrictions on housing density.

${ }^{4}$ It can be the case that no sale is made and the owner of undeveloped land simply becomes the owner of new housing. This is rare for the large publicly-listed housing development companies we study in the next sections.
} 
testable prediction of the static model is that the residual planned stock will be correlated with new housing supply as suppliers quickly adjust through the production system towards the new static equilibrium.

Finally, voluntary delays by housing developers in navigating the housing production process should be rare, in fact, non-existent, as their incentive is always to push towards the equilibrium in which there are no remaining development opportunities. In sum, looking at the housing production process through the lens of the static model of housing supply provides the following testable predictions about patterns that should be in the housing production data.

1. Inventories are minimised while the flow rate of new sales (and therefore housing production) is maximised. If planning approvals involve significant delays then high inventories of residual planned stock may need to be held, but after approval inventories of approved stock will be minimised through rapid selling.

2. Changes in the residual planned stock of a region will correlate with the rate of new home production.

3. Voluntary delays to production are costly and will be rare.

\subsection{Data description}

To test these predictions, we first use data from the annual reports of the eight largest publiclylisted residential development companies on the number of new sales of residential lots and housing (including apartments), and the stock of lots approved, or zoned, for residential use their landbank, which includes land held in joint ventures or under options contracts for purchase. This provides a database of 110 yearly data points across eight developers for the new housing lots (including apartment lots) these companies can produce using their currently-owned stock of approvals and residual planned housing. This data is summarised in Table 1, with the total housing supply by this sample of developers representing $9 \%$ of the 181,000 new homes (detached houses and apartments) built in Australia per year in the period covered by the data (ABS, 2019).

To understand the private developer decisions at latter production stages we also compile recent data where available from these annual reports on the rate of sales of specific residential subdivisions that have already been 'released to market', their total size in terms of new housing lots, their age and cumulative sales, providing a database of 249 data points from 2014 to 2018 from the developers Stockland, Sunland, and Mirvac for subdivisions in New South Wales, Queensland, Victoria and Western Australia. The mean sales, remaining lots, and subdivision size are reported in the final rows of Table 1.

Second, we data on the planning process in Queensland. For the six of the largest council areas in Queensland, the data contains estimates of the residual planned stock of detached housing lots (including townhouses) compiled by government statisticians from 2013 onwards, providing 126 data points on the stocks and flows across the complete planning process. These councils represent $79 \%$ of all new lot production in Queensland over the period. In addition, for all 35 councils in Queensland, data is available on the flows in and out of the stock from new approvals, the rate of lot production from the approved stock, and lapses in approvals (which happen when approvals expire after six years without housing being produced). This provides a database of 2,426 quarterly data points - from March 1999 to September 2018 - for detached housing and townhouse lots. Table 2 summarises the key variables in this data.

Third, for qualitative data, we look at statements about the rate of new housing supply from Australia's largest eight publicly listed residential property development companies. We compare 
Table 1: Listed developer residential sales and land bank

\begin{tabular}{llrrr}
\hline \hline Developer & $\begin{array}{l}\text { Date } \\
\text { range }\end{array}$ & $\begin{array}{r}\text { Mean } \\
\text { sales }\end{array}$ & $\begin{array}{r}\text { Mean } \\
\text { landbank }\end{array}$ & $\begin{array}{r}\text { Mean } \\
\text { years supply }\end{array}$ \\
\hline FKP & $2009-2013$ & 463 & 6,529 & 14 \\
Sunland & $2007-2018$ & 644 & 4,857 & 8 \\
Villaworld & $2005-2018$ & 849 & 5,334 & 6 \\
Mirvac & $2003-2018$ & 2,332 & 26,379 & 11 \\
Frasers/Australand & $2003-2018$ & 2,575 & 17,658 & 7 \\
PEET & $2007-2018$ & 2,623 & 44,457 & 17 \\
Lendlease & $2001-2018$ & 2,960 & 46,032 & 16 \\
Stockland & $2002-2018$ & 5,053 & 67,626 & 13 \\
\hline Per developer per year & $2001-2018$ & 2,464 & 30,744 & 12 \\
Total per year & $2004-2018$ & 16,619 & 212,945 & 13 \\
Maximum year (totals) & 2016 & 22,913 & 252,903 & 11 \\
\hline Approved and released subdivisions & & & & \\
Per subdivision per year (lot balance) & $2014-2018$ & 119 & 960 & 8 \\
Mean total subdivision size & & & 1,910 & 16 \\
\hline \hline
\end{tabular}

Frasers/Australand excludes 2014 data from the takeover year. Landbank is measured as the number of residential lots (dwellings or land) expected to be built on land controlled by the reporting entity. Mean total subdivision size reflects the total lots in each subdivision and provides a reference point for the rate at which each subdivision is sold, irrespective of whether the first or final lots are being sold.

media statements to statements made in their annual reports, allowing us to filter out convenient political stories told to the media from true company intentions that are legally required to be reported to shareholders.

\subsection{Methods}

The three predictions of the static model are tested on the data as follows. For the prediction that landbanks are costly inventories that are minimised, we first evaluate the plausibility of the summary data of housing developer landbanks being consistent with the static model prediction of the function of inventories. More specifically, we estimate the model

$$
\text { landbank }_{i, t}=\alpha \text { sales }_{i, t}+C_{i}+\epsilon_{i, t}
$$

where landbank is their inventory of housing lots for developer $i$ at time $t$, and is dependent variable that is thought to be minimised based on sales conditions, sales is the number of annual sales of a developer, and $C$ are developer controls if included, and $\epsilon$ is an error term. While the estimate of $\alpha$ is going to match the mean years supply per developer per year in Table 1 (without controls), the goodness of fit indicates the degree to which this measure represents the complete data. The static model expectation of $\alpha$ depends upon the assumption of what plausible inventory minimisation looks like. The size of $\alpha$ maps to the year's of inventory held. If inventory is managed so as to be held for one year, then $\alpha$ will be one. In fact, annual flows 
Table 2: Queensland planning system summary statistics

\begin{tabular}{clr}
\hline \hline & Planning & Mean per council \\
& system metric & per quarter \\
\hline & Approved stock & 8,458 \\
Six councils & Lot approvals/qrtr & 688 \\
N=126 & Lot lapses/qrtr & 32 \\
Sept 2013 - Sept 2018 & Lot production (total/qrtr) & 483 \\
& Planned stock & $\mathbf{6 1 , \mathbf { 1 4 4 }}$ \\
\hline Statewide & Approved stock & 2,642 \\
$(35$ councils) & Lot approvals/qrtr & 208 \\
N=2,426 & Lot lapses/qrtr & 29 \\
Mar 1999- Sept 2018 & Lot production (total/qrtr) & 142 \\
\hline \hline
\end{tabular}

Six councils are Brisbane, Gold Coast, Ipswich, Logan, Moreton Bay and Sunshine Coast.

may even exceed the approved stock if inventory is managed so as to be held for less than one year. How close the balance of approved lots is to the flow of sales is a measure of the degree to which private developer decisions conflict with the static model.

However, it may be the case that planning delays or uncertainty require extensive landbanks to be held prior to approvals, and that planning delays may be the cause of a large $\alpha$. We therefore also regress this model on our data of landbanks of approved stock already released for sale and the sales rates of these subdivision, using both the total subdivision size and the remaining balance of lots in the subdivision as landbank measures. This eliminates planning delays as a causal explanation of large landbanks, as the flows in the housing production process at this stage are governed only by the decisions of private developers. Again, if each subdivision that is approved and already released for sale is fully sold within one year of its first sale, the estimated $\alpha$ should be one. A large $\alpha$ in these models implies that housing developers intentionally retain high inventories of profitable housing lots rather than build housing. To cross-check whether this argument can be supported, we look at qualitative evidence from statements made in the annual reports of these developers about how they manage their landbank inventories.

To test the prediction that changes in the residual planned stock across a region correlates with the rate of new home production we use the Queensland planning system data and estimate a model of quarterly detached housing production as a linear function of the residual planned stock in the form

$$
\text { lots }_{i, t}=\alpha+\beta \text { planned } \text { stock }_{i, t}+C_{i}+\epsilon_{i, t}
$$

where lots is the rate of new lot production per quarter, planned stock is the total planned stock, $C$ represents a variety of controls, such the approved stock, council, and average land price, and $\epsilon$ is an error term. A large, positive, and significant $\beta$ is expected by the static model of housing supply. We also apply this model to the full Queensland data with approved stock as the dependent variable, and including other variables such as lapses in approvals.

Finally, to test the prediction that voluntary delaying behaviour by developers is rare, we sum- 
marise five delaying behaviours that are explained to investors in annual reports, but that cannot be explained in the static economic model of housing supply.

\section{Results}

\subsection{Inventory minimisation prediction}

The left panel of Figure 2 shows the relationship between developer landbanks of total planned stock and their annual sales, plotting the total landbank data summarised Table 1. The dashed blue line is the linear best fit of Equation 1 (reported as Model (1) in Table 3), and the dashed orange line is the prediction if inventory is held for one year (i.e. the rate of sales equals the landbank, $\alpha=1$ ). The tight model fit shows that landbanks are systematically over twelve times higher than if they were inventories held for one year on average. This degree of landbanking is similar to comparable large-scale housing developers in the United Kingdom that have around twelve years of land supply on their balance sheets - six year of approved lots, and another six years of 'strategic land banks' (Jeffreys, 2016). Adding developer controls reduces the sales coefficient to 5.8 , showing that at their mean landbank size, 5.8 lots are added to landbanks for each additional annual sale.
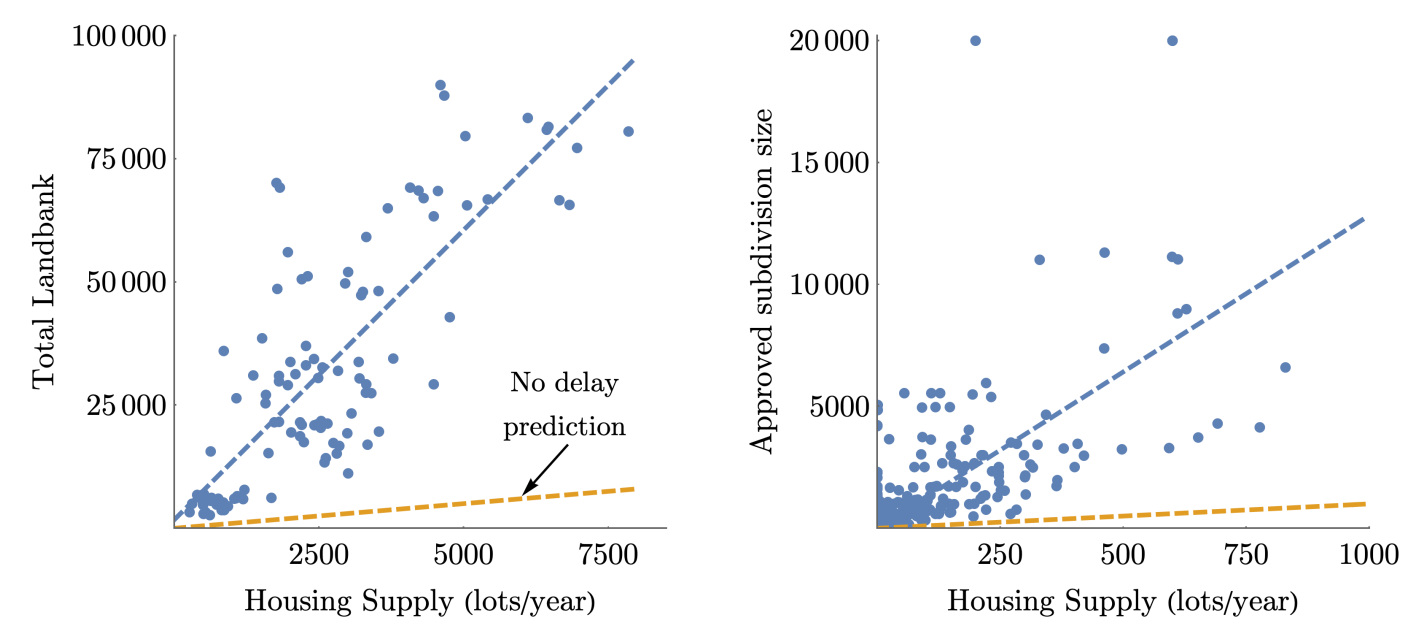

Figure 2: Developer landbank and sales relationships

On the right panel of Figure 2 is the relationship between the lot size of subdivisions approved and already for sale, and the sales rate per year of that subdivision, with Models (3) and (4) in Table 3 showing model results. In contrast to the story that planning approvals require large landbanks to be held, these model results are similar to the total landbank models. If only the remaining balance of lots in subdivision is used as the independent inventory variable, then the estimated $\alpha$ falls to six, as shown in Models (5) and (6). Other data features support the case that landbanks are not held because of planning delays. The average age of approved subdivisions since their site purchase is nine years, the median age is ten years, and the maximum is 23 years. Furthermore, 48 out of these 249 subdivision observations had no sales in the prior year, and one subdivision even had 'negative sales' due to contract withdrawals being higher than new sales contracts in that year (which was coded as zero new sales). 
Table 3: Lot production and planned stock (detached housing lots) relationships

\begin{tabular}{lcccccc}
\hline \hline Dependent var: & \multicolumn{2}{c}{ Total } & \multicolumn{2}{c}{$\begin{array}{c}\text { Subdivision size } \\
\text { Landbank }\end{array}$} & \multicolumn{2}{c}{$\begin{array}{c}\text { Remaining landbank } \\
\text { of approved stock }\end{array}$} \\
of approved stock \\
Model: & $(1)$ & $(2)$ & $(3)$ & $(4)$ & $(5)$ & $(6)$ \\
\hline Sales & $12.3^{* * *}$ & $5.8^{* * *}$ & $12.8^{* * *}$ & $10.8^{* *}$ & $6.9^{* * *}$ & $6.2^{* * *}$ \\
Developer controls & $\mathrm{N}$ & $\mathrm{Y}$ & $\mathrm{N}$ & $\mathrm{Y}$ & $\mathrm{N}$ & $\mathrm{Y}$ \\
$\mathrm{N}$ & 110 & 110 & 249 & 249 & 249 & 249 \\
$\mathrm{R}^{2}$ & 0.87 & 0.94 & 0.55 & 0.58 & 0.28 & 0.29 \\
\hline \hline
\end{tabular}

Notation: ${ }^{*}$ is $p<0.1,{ }^{* *}$ is $p<0.05,{ }^{* * *}$ is $p<0.01$. All Models are: dependent var $=$ $c+\alpha$ independent vars + controls $+\epsilon$. Adding year controls made little difference to the direction, size, or significance of these relationships.

This evidence is consistent with Australia data on planning approvals. In Sydney and Melbourne, where over $94 \%$ of planning applications that are made are approved, these approvals typically take just three to four months (Gurran \& Phibbs, 2014, pp.237-238). In Queensland, most councils have a fast-tracked process the guarantees a turn-around time of five business days for applications with 10 or fewer housing lots, which is used for $20 \%$ of planning applications in Brisbane (Brisbane City Council, 2018). Even exceptionally large projects in Queensland, like Stockland's Caloundra South project, which is expected to produce over 20,000 dwellings alongside numerous retail and commercial lots over a 25-35 year period, gained high-level planning approval in 12 months Allen (2011). Planning delays cannot explain the observed landbanks.

Statements by these developers in their annual reports confirm that the large landbanks and slow sales are due to their own intentional private decisions. For example, LendLease noted in their 2018 annual report the following.

The Communities pipeline consists of an estimated 52,333 lots. With an annual target of 3,000 to 4,000 completions, more than a decade of supply has already been secured. The development pipeline provides long term earnings visibility and the flexibility to be both disciplined and patient with the pursuit of future opportunities. (Lendlease, 2018, p.76)

Instead of maximising sales they target a minimal rate of conversion of land to new housing of just "1,000 to 2,000 apartments per annum" and "3,000 to 4,000 completions". But when speaking to the media, these same companies claim they are only holding landbank inventories due to costly regulatory delays, as the following quotation shows.

Developer Stockland said it has endeavoured to bring projects onto the market as quickly as it can clear complex approval processes, often through multiple local, state and federal authorities. "It is costly and inefficient for developers to hold inactive land," Stockland residential chief executive Andrew Whitson said.(Tan, 2016)

Yet Stockland's annual reports show that for the three years before this statement they held 52,057 lots in projects that were zoned for housing but not even yet for sale because of their own decisions to delay planning applications and sales. They also reported to investors their plan to sell just 300-900 new housing lots per year from their approved Caloundra South project that contains over 20,000 lots Allen (2011).

The reason for holding large landbanks seems to be capital returns. During a period of housing 
price declines in 2010-2011, the listed developer PEET noted that they were strategically reducing their landbank (by selling it rather than producing new housing) because they preferred to expose their capital to other returns rather than the declining returns from owning undeveloped land.(PEET, 2011). During the 2018 home price downturn, another developer, Stockland, started to reduce its landbank, seeking to sell an approved and partially-developed site with 2,000 lots remaining unsold in order to change their capital return profile.

Development giant Stockland is quietly shopping around one of its best-selling Melbourne residential estates, as it comes under pressure to improve its balance sheet amid the housing slowdown. (Schlesinger, 2018)

The prediction of static economic models that approved landbanks are inventories and will be minimised does not fit the data. Instead, even approved and released subdivisions typically take twelve years to sell. Company statements about landbanking show that rather than being costly inventory, landbanks are capital assets that are actively managed with purchases and sales through the property cycle to earn capital returns.

\subsection{Correlation between Planned Stock changes and new housing}

The second prediction of the static housing supply model is that the residual planned stock will correlate with the rate of housing supply at a regional level. Figure 3 plots the planned stock of detached housing lots (left panel), and the quarterly production of detached housing lots (right panel) over time using the data on six Queensland councils. The $16 \%$ reduction in planned stock over this period was related to an increase, rather than a decrease, in the rate of new housing production. This decline in planned stock was mostly because there were few changes to zoning for detached housing, yet production of detaching housing continued, reducing the stock.
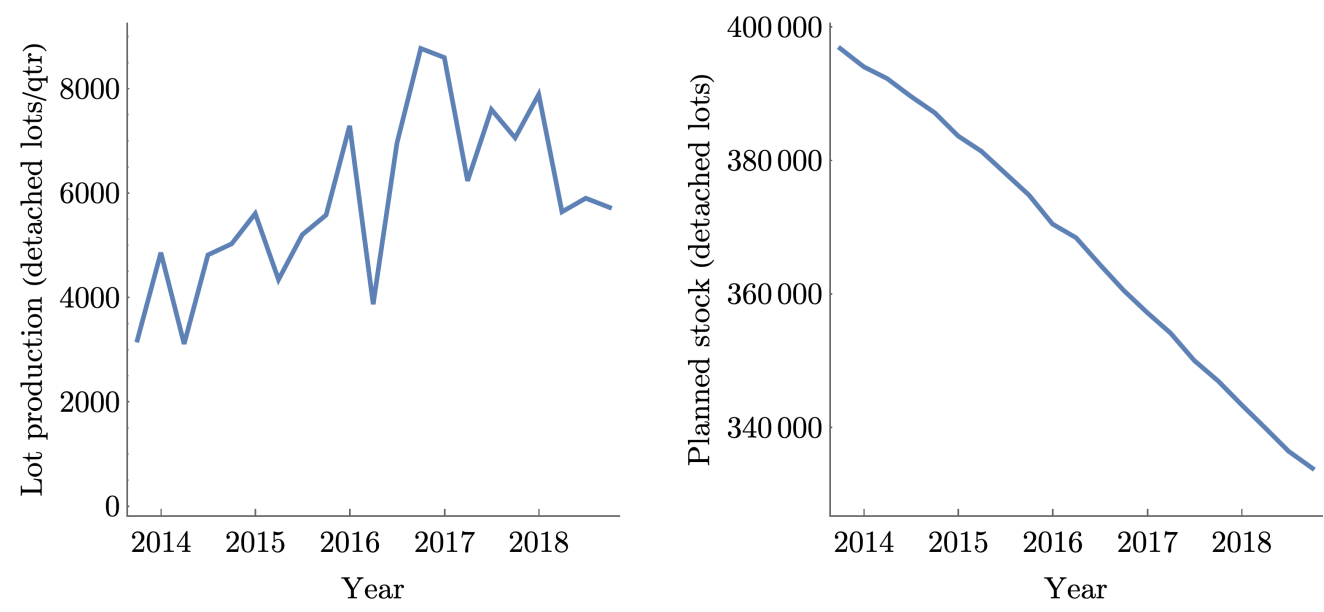

Figure 3: Lot production and planned stock over time (six local councils)

Models (1) and (2) of Table 4 show the Equation 2 regression results (with and without council controls), confirming the negative relationship and its statistical fit. We add additional independent variables to this modelling exercise to look at the combined effect of planned stock and approved stock at a regional level on detached housing lot production. In Models (3) and (4) we see that the same relationship with planned stock holds, and there is no significant relationship 
with the approved stock. For completeness, we add land prices in Models (5) and (6), which seem positively related, but after adding council controls, might simply have been capturing the fact that councils with higher average land values had higher lot production. In all, these results suggest that changing the planned stock though rezoning and other planning changes will not rapidly flow through to new housing production.

Table 4: Lot production and planned stock models for six councils

\begin{tabular}{lcccccc}
\hline \hline Dependent var: & \multicolumn{5}{c}{ Detached housing lot production (quarterly) } \\
Model: & $(1)$ & $(2)$ & $(3)$ & $(4)$ & $(5)$ & $(6)$ \\
\hline Planned stock & $-0.002^{* * *}$ & $-0.02^{* * *}$ & $-0.002^{* * *}$ & $-0.01^{* * *}$ & $-0.002^{* * *}$ & -0.01 \\
Approved stock & & & $0.01^{*}$ & 0.02 & $0.02^{* * *}$ & 0.01 \\
Land price/sqm & & & & & $0.77^{* * *}$ & 0.66 \\
Council controls & $\mathrm{N}$ & $\mathrm{Y}$ & $\mathrm{N}$ & $\mathrm{Y}$ & $\mathrm{N}$ & $\mathrm{Y}$ \\
$\mathrm{N}$ & 126 & 126 & 126 & 126 & 126 & 126 \\
$\mathrm{R}^{2}$ & 0.11 & 0.31 & 0.13 & 0.32 & 0.28 & 0.33 \\
\hline \hline
\end{tabular}

Notation: ${ }^{*}$ is $p<0.1,{ }^{* *}$ is $p<0.05,{ }^{* * *}$ is $p<0.01$. Adding year controls made little difference to the direction, size, or significance of these relationships.

We turn now to the flows in and out of the approved stock from the full dataset of all council areas. We show the data in Figure 4, with the left panel showing the relationship with between the approved stock and lot production (for detached housing and townhouses only). The dashed blue line is the linear best fit (as per Model (1) in Table 5) and the dashed orange line is the rate of lot production if all approved lots are produced within one year (i.e. quarterly lot production is a quarter of approved stock). Notice that in some periods there is a high flow of production relative to stocks (i.e. stocks of approvals are about one-years supply), but this is the exception. On average there are 4.8 years of supply in the approved stock, though there are many quarters where there are no new homes produced in some council areas, despite a large approved stock. For example, for four quarters between 2016 and 2018 there were no new housing lots produced in the Gladstone council area, despite a stock of over 4,000 approved lots.
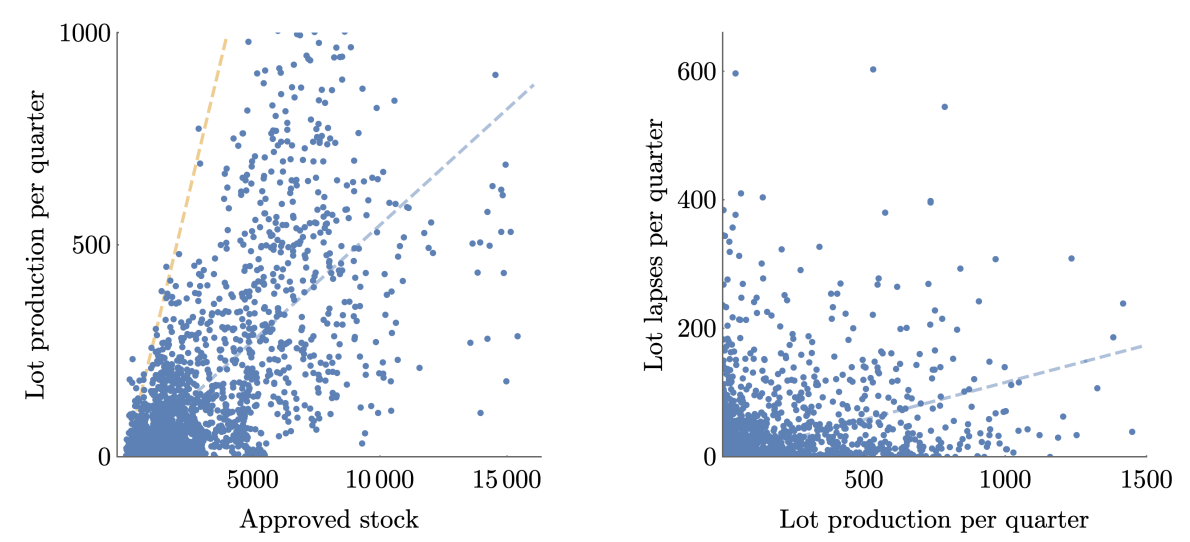

Figure 4: Lot production, lapses and approved stock (detached housing lots)

The right panel of Figure 4 shows an unexpected relationship between the flows out of the 
approved stock from new lot production and also the flows in the reverse direction due to lapsing approvals which have not been developed within their six year time limit. This is a puzzle for static economic models in which landbank inventories are developed as rapidly as possible. Instead, when lot production and approved stocks are high, so too is a delaying behaviour of letting approvals lapse. We demonstrate the extent of the relationships between approved stock, lot production, lapses, and new approvals, in the model results of Table 5 . The variation in approved stock seems to be closely related to lot production, as expected. Lapses in approvals are strongly correlated with lot production in Models (3) and (5), but including council controls weakens the relationship and reverses the sign of the coefficient (Models (4) and (6)). This arises because the high approvals and high lapses relationship is dominated be a consistent council effect, whereby larger councils consistently have more lot production and lapses, as well as larger approved stocks.

Taken together, the housing production data across Queensland looks quite different to the static model predictions. However, the patterns here are consistent with survey research of housing development. In a 2008 survey of residential developers in the United Kingdom, for example, only two out of 18 developers surveyed thought that allocating "significantly more land for housing development over the next ten years" would significantly increase the rate of new housing supply (Adams et al. , 2009). In addition, a recent survey of Australian residential developers contained responses that explained how they "were careful not to over supply a particular type of housing project, at a particular price, in a particular location" (Lewis, 2017, p87). In other words, market participants themselves, who publicly argue for increasing the total available land for housing in a city, think that changing the total planned stock of land in a city through rezoning will have no effect on the rate of new housing supply.

Table 5: Models of detached housing lot production in Queensland

\begin{tabular}{lcccccc}
\hline \hline Dependent var: & \multicolumn{5}{c}{ Detached housing lot production (quarterly) } \\
Model: & $(1)$ & $(2)$ & $(3)$ & $(4)$ & $(5)$ & $(6)$ \\
\hline Approved stock & $0.06^{* * *}$ & $0.01^{* * *}$ & $0.05^{* * *}$ & $0.01^{* * *}$ & $0.03^{* * *}$ & $0.005^{* * *}$ \\
Lapses & & & $0.27^{* * *}$ & $-0.08^{* *}$ & $0.23^{* * *}$ & $-0.06^{*}$ \\
Approvals & & & & & $0.03^{* * *}$ & $0.16^{* * *}$ \\
Council controls & $\mathrm{N}$ & $\mathrm{Y}$ & $\mathrm{N}$ & $\mathrm{Y}$ & $\mathrm{N}$ & $\mathrm{Y}$ \\
$\mathrm{N}$ & 2,426 & 2,426 & 2,426 & 2,426 & 2,426 & 2,426 \\
$\mathrm{R}^{2}$ & 0.49 & 0.82 & 0.49 & 0.74 & 0.60 & 0.77 \\
\hline \hline
\end{tabular}

Notation: ${ }^{*}$ is $p<0.1,{ }^{* *}$ is $p<0.05,{ }^{* * *}$ is $p<0.01$. Adding year controls and lagging approvals (from one to four quarters) made little difference to the direction, size, or significance of these relationships.

\subsection{No developer delaying behaviour}

Despite the static model prediction of no voluntary delaying behaviour, the following delaying behaviours are commonly mentioned in the annual reports of listed housing developers or in the media.

1. Staging large developments by breaking them into smaller subdivisions. Rather than accelerating home production by bringing as much new housing to market as possible, staging slows the rate of new housing supply on available land. 
2. Gaming sunset clauses on off-the-plan new housing contracts. These contract clauses allow for the developers to pull out of the home purchase contract without significant penalties if the development is unable to be completed by the agreed date. During periods of rapid price growth developers can delay construction and use these contract clauses to reclaim ownership of the previously sold housing to then re-sell at higher prices (see Thomson (2018)).

3. Option contracts for site purchases. These contracts allow developers to secure future development sites with little upfront cost while delaying building housing on those sites. A faster way to secure land for development is to purchase immediately or undertake a joint venture with the previous landowner. For example, the largest residential developer in Australia, Stockland, signed a 31-year option contract in 2010 with a landowner to acquire a property expected to produce 11,500 new dwellings in a number of staged parcels (AAP, 2010).

4. Renegotiating planning approvals. If home prices rise quickly after a planning approval is granted, the optimal density of the development may have increased. To capture that higher return requires seeking a new approval for a more dense subdivision. For example, in 2013 Stockland reported to investors that it had nine inactive residential subdivisions, with a total potential housing supply of 41,200 lots, that it was delaying for at least four years in order to "improve return prior to launch."

5. Reducing sales volumes rather than prices. If a housing developer is able to supply 5,000 new dwellings per year when prices are rising (i.e. demand for new housing is high), they can typically also supply 5,000 per year when prices are falling. However, they do not. Instead, they reduce the rate of new supply rather than the price in response to declining demand, often offering non-monetary incentives to buyers, which makes little sense in a static model of housing supply. In fact the opposite behaviour is expected. If landbanks are inventories, prices will typically be reduced to increase sales to clear inventory of bad production decisions. This behaviour is also found in surveys of housing developers, as the following quotation shows.

...the usual practice in the industry is to aim for the maximum possible price and accept a slower rate of sales. As a different interviewee remarked: 'In a buoyant market, developers are willing to put the prices up as far as they possibly can.' Another aimed 'to pitch at maximum price at the start and then use incentives (carpets, white goods etc) if prices need to be reduced.' And yet another directly linked land shortages to price maximisation, commenting that 'if you're in an area with little or no new housing, you have a throttle on new product. (Adams et al. , 2009, p. 303)

Figure 5 shows the variation of new home sales for four of the largest housing developers in Australia. Notice that the enormous variation in the number of sales made each year. The shaded dashed orange line is the price growth of the national home price index (ABS, 2018a). The fact that the peak sales rates are rarely sustained in periods of falling prices indicates that these high sales volumes are closely related to the market cycle rather than the physical, or regulatory, ability to supply new homes. 
Lendlease

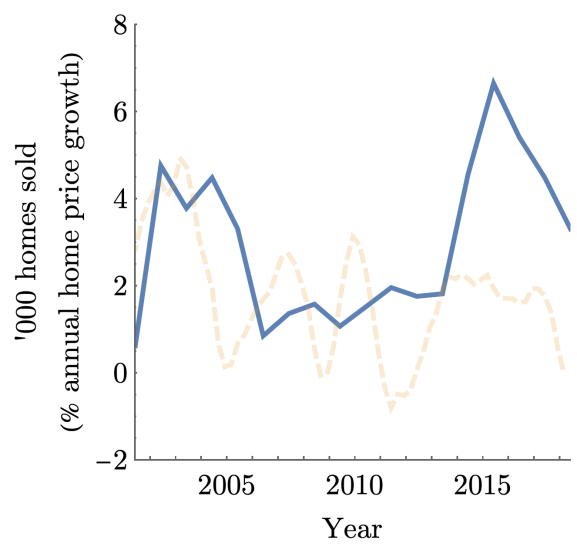

PEET

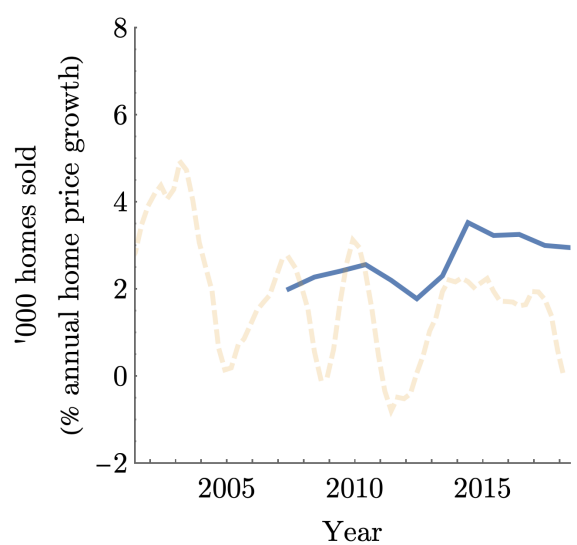

Stockland

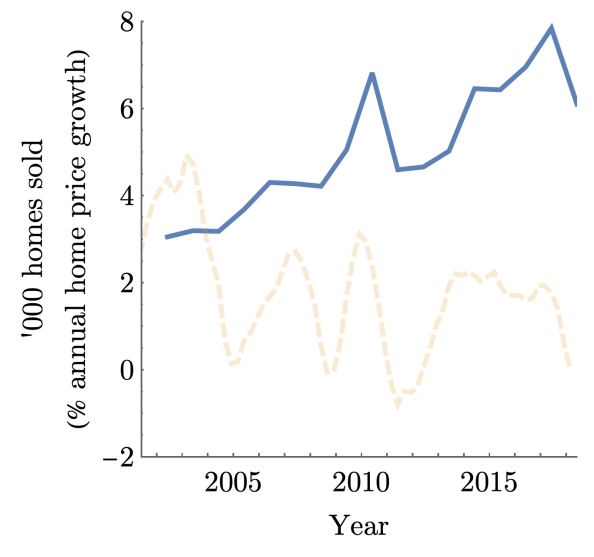

Mirvac

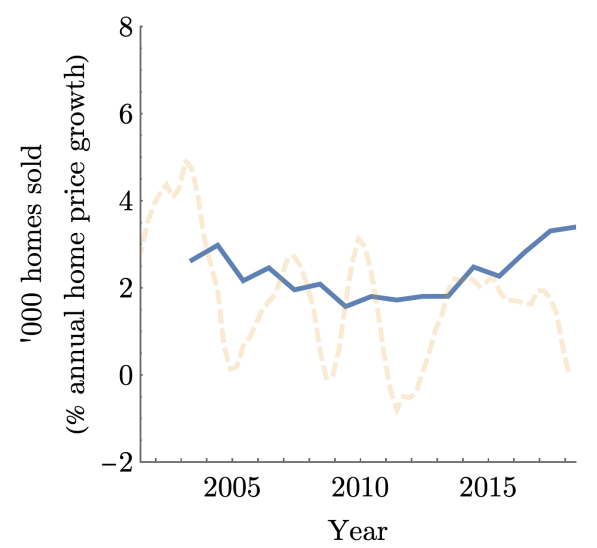

Figure 5: Listed developer annual new residential sales (national home price growth, dashed)

\section{Discussion and Conclusion}

Static economic models of housing supply assume that all housing that meets the condition $r>(l+c) i$ is immediately produced. These simple models have been relied upon to reason about the effect of changes to planning controls on new housing supply, and hence prices. However, the predictions of these models about housing production behaviour are not borne out in the data. Instead of landbanks being costly inventories that are minimised with rapid housing construciton, as static models assume, the evidence suggests that they are instead capital investments that earn a return even without housing production.

A capital budgeting approach informed by real options theory may help shed some light on the observed landbanking behaviour and provide directions for future research. This approach maximises returns to capital budgets, conditional upon risk, through capital reallocation decisions. In capital budget terms, the change in return from converting land and cash into housing is $R_{H_{t}}-\left(R_{L_{t}}+R_{C}\right)$, where $R_{H_{t}}$ is the total return from a home, $R_{L_{t}}$ is the total return from the land input per dwelling, and $R_{C_{t}}$ is the total return from the necessary cash for development. 
A positive change in this rate of return (adjusting for risk) is necessary for new housing to be viable in a dynamic capital budgeting model.

$R_{H_{t}}$ includes the change in home value plus current rental return, or $R_{H_{t}}=\dot{P}_{t}+r_{H_{t}}$ where $\dot{P}_{t}$ is the exogenous change in home price, and $r_{H_{t}}$ is the net rent. The return to cash needed to construct a home, $R_{C_{t}}$, is the nominal interest rate, $i$, multiplied by the development cost (construction plus other fees, taxes or charges) of a home, $c$. We simplify here by assuming for now that $c$ and $i$ do not vary over time. This means that rising home prices (not high price levels) increase the relative return of housing over cash, creating a strong incentive to shift balance sheets away from cash and towards housing to earn higher overall returns. High price growth attracts its own demand.

For undeveloped land the total return, $R_{L_{t}}$, is the sum of the value change plus rents from lower-value uses, $r_{L_{t}}$, which are zero when vacant, the total being $R_{L_{t}}=\dot{L}_{t}+r_{L_{t}}$, where $\dot{L}_{t}$ is the change in land value. The change in the value of undeveloped land includes the change in home prices because land values are the residual of prices minus development costs. But it also includes the change in the option value because the optimal density of a subdivision also changes with home prices, which we call the option premium and denote $\omega .{ }^{5}$ For simplicity we assume that $\omega$ is a linear function of $\dot{P}_{t}$ at the margin, but this need not be the case depending on how optimal density changes with home price levels. Our land price growth term then becomes $\dot{L}_{t}=\dot{P}_{t}+\omega \dot{P}_{t}$, and the total return to an amount of land currently needed for one home at the optimal density is $R_{L_{t}}=\dot{P}_{t}+\omega \dot{P}_{t}+r_{L_{t}}$.

After substituting our returns for each component we get "return profits", $\pi_{R_{t}}$, of

$$
\begin{aligned}
\pi_{R_{t}} & =\dot{P}_{t}+r_{H_{t}}-\left(\dot{P}_{t}+\omega \dot{P}_{t}+r_{L_{t}}+c i\right) \\
& =r_{H_{t}}-\left(\omega \dot{P}_{t}+r_{L_{t}}+c i\right) .
\end{aligned}
$$

Therefore, supplying new homes only increases the total return to the landowner if

$$
r_{H_{t}}>\omega \dot{P}_{t}+r_{L_{t}}+c i
$$

This economic hurdle for profitable development is a more challenging one than the standard model which ignores price dynamics ${ }^{6}$, and where the condition for new supply is simply when price exceeds input costs, or $r_{H}>(L+c) i$. Taking this dynamic view shows that higher home price growth can reduce the willingness to supply new housing at that time, consistent with other dynamic models such as Capozza \& Li (1994), who showed that "higher growth expectations

\footnotetext{
${ }^{5}$ For example, a site that is currently optimally subdivided into 10 lots might be optimally subdivided into 12 slightly smaller lots if home prices in the area increase from $\$ 300,000$ to $\$ 350,000$. Instead of the return to undeveloped land being $\$ 500,000$ due to the home price gain alone $(10 \times \$ 50,000)$, the return now includes the full value of two additional lots. As long as the price effect of producing smaller lots is less than proportional to the size decrease of each lot, the total return will be higher. In this example, as long as price of the smaller lots exceeds $\$ 292,000$, the total return to land exceeds the home price growth. If we take the case where the price of the twelve smaller lots is $\$ 310,000$ each, then $\omega=0.44$ and the option premium is $\$ 220,000$, while the return from home price growth alone is $\$ 500,000$, for a total return of $\$ 720,000$. The return to land from the option premium is $(\$ 310,000 \times 12)-(\$ 350,000 \times 10)=\$ 220,000$, while the return from home price growth alone is $(\$ 350,000 \times 10)-(\$ 300,000 \times 10)=\$ 500,000$, giving a total return to keeping land undeveloped of $\$ 720,000$.

${ }^{6}$ Indeed, there will also be price dynamic effects from a developer's own new housing supply that we have not incorporated.
} 
always raise the hurdle rent", and Lange \& Teulings (2018) who conclude that "investment should be delayed when growth is high", and Murphy (2018), who note that "rising prices make building today more attractive, but also make waiting more attractive, thus reducing the responsiveness to price."

Many of the static model results do not hold even in this very simple dynamic capital budgeting model. For example, a binding density constraint - in the form of a height limit, floor-area-ratio, or minimum lot size- decreases $r_{H_{t}}$, since it decreases the number of new homes able to be built per unit of land. This effect would decrease the incentive to develop. But a binding density constraint also removes the option premium earned by keeping land undeveloped, meaning that $\omega=0$. This change has the opposite effect of increasing the incentive to develop into new housing sooner. Only the net effect matters, and the supply condition of this simple dynamic model suggests that in times of high home price growth that the effect on the option premium will be relatively large compared to the effect on relative rents, and relaxing density constraints could perhaps delay new housing. This is consistent with Titman's (1985) real options analysis that showed density constraints may inadvertently increase the rate of new housing supply, and Jou and Lee's (2007) analysis that density constraints can increase or decrease new housing supply depending on the relative effect on rents and the return to delaying development. Another example is to consider how taxes change housing supply incentives. In theories where land prices are treated as an exogenous input costs of development, impact fees on development add to development costs and reduce supply. However, in this theory, impact fees are development costs that reduce the land value of undeveloped land and reduce the growth in the value of the option premium because they add an additional cost on developing at higher densities (they reduce $\omega$ ). This has the effect of bringing forward development without adding to home prices, which is consistent with previous empirical studies (Murray, 2018).

The demonstrated existence of extensive landbanks suggests that the economic logic of policies that relax planning controls in order to increase housing supply and lower home prices are flawed, at least in Australia. This paper has examined in detail the patterns of landbanking amongst listed residential developers in Australia, and the relationships between the zoned planned stock, planning approvals, and new lot production in the planning system in Queensland. While observational, these empirical patterns, coupled with the shareholder reporting and survey responses of developers, paint a compelling picture that town planning regulations are not the binding constraint on the rate of new housing supply. Only because to the application of inappropriate static economic models has housing supply policy focussed so strongly on planning regulations as a cause of high prices.

\section{References}

AAP. 2010. Stockland buys $\$ 4$ b site for new suburb. Sydney Morning Herald, December.

ABS. 2018a. 6416.0 Residential Property Price Indexes: Eight Capital Cities.

ABS. 2018b. 8752.0 Building Activity, Australia.

ABS. 2019. 8752.0 Building Activity, Australia. Table 37 - Number of Dwelling Units Completed by Sector. Tech. rept. Australian Bureau of Statistics.

Adams, David, Leishman, Chris, \& Moore, Craig. 2009. Why not build faster?: Explaining the speed at which British house-builders develop new homes for owner-occupation. Town Planning Review, 80(3), 291-314. 
Allen, Ben. 2011 (November). Caloundra South Investor Tour. Tech. rept. Stockland.

BARKer, KAte. 2005. Review of Housing Supply. Final Report - Recommendations. Tech. rept. HM Treasury.

Brisbane City Council. 2018 (June). RISKsmart guidelines. Tech. rept.

Callcutt, John, Britain, Great, et al. . 2007. The Callcutt Review of housebuilding delivery. Communities and Local Government Publications.

Capozza, Dennis, \& Li, Yuming. 1994. The Intensity and Timing of Investment: The Case of Land. The American Economic Review, 84(4), 889-904.

COAG. 2012. Housing Supply and Affordability Reform. Council of Australian Governments.

Costello, Greg, \& Rowley, Steven. 2010. The Impact of Land Supply on Housing Affordability in the Perth Metropolitan Region. Pacific Rim Property Research Journal, 16(1), $5-22$.

Daley, John, Coates, Brendan, \& Wiltshire, Trent. 2017. Submission to the NSW Legislative Assembly Committee on Environment and Planning Inquiry into Land Release and Housing Supply in NSW.

Daley, John, Goss, Peter, Duckett, Stephen, Norton, Andrew, Terrill, Marion, Wood, Danielle, Wood, Tony, \& Coates, Brendan. 2019. Commonwealth Orange Book 2019: Policy priorities for the federal government. Tech. rept. Grattan Institute.

Davidoff, Thomas. 2016. Supply Constraints Are Not Valid Instrumental Variables for Home Prices Because They Are Correlated With Many Demand Factors. Critical Finance Review, 5(2), 177-206.

DiPAsquale, Denise. 1999. Why don't we know more about housing supply? The Journal of Real Estate Finance and Economics, 18(1), 9-23.

Follain, JAmes R. 1979. The price elasticity of the long-run supply of new housing construction. Land Economics, 55(2), 190-199.

Glaeser, Edward, \& Gyourko, Joseph. 2002. Zoning's steep price. Regulation, 25, 24.

Glaeser, Edward, \& Gyourko, Joseph. 2018. The Economic Implications of Housing Supply. Journal of Economic Perspectives, 32(1), 3-30.

Glaeser, Edward L., \& Gyourko, Joseph. 2003. The Impact of Building Restrictions on Housing Affordability. Federal Reserve Bank of New York Policy Review, 9(2), 21-39.

Glaeser, Edward L, \& WArd, Bryce A. 2009. The causes and consequences of land use regulation: Evidence from Greater Boston. Journal of Urban Economics, 65(3), 265-278.

Glaeser, Edward L, Gyourko, Joseph, \& Saks, Raven E. 2005. Urban growth and housing supply. Journal of Economic Geography, 6(1), 71-89.

Glaeser, Edward L., Gyourko, Joseph, \& Saiz, Albert. 2008. Housing supply and housing bubbles. Journal of Urban Economics, 64(2), 198 - 217.

Glaeser, Edward L., Gyourko, Joseph, Morales, Eduardo, \& Nathanson, Charles G. 2014. Housing dynamics: An urban approach. Journal of Urban Economics, 81, $45-56$. 
Gomez-Gonzalez, Jose Eduardo, Gamboa-Arbeláez, Juliana, Hirs-Garzón, Jorge, \& Pinchao-Rosero, Andrés. 2018. When bubble meets bubble: Contagion in OECD countries. The Journal of Real Estate Finance and Economics, 56(4), 546-566.

Gurran, Nicole, \& Phibbs, Peter. 2013. Housing supply and urban planning reform: the recent Australian experience, 2003-2012. International Journal of Housing Policy, 13(4), 381-407.

Gurran, Nicole, \& Phibbs, Peter. 2014. Evidence-free zone? Examining claims about planning performance and reform in New South Wales. Australian Planner, 51(3), 232-242.

Gurran, Nicole, \& Phibbs, Peter. 2015. Are governments really interested in fixing the housing problem? Policy capture and busy work in Australia. Housing Studies, 30(5), 711-729.

Gyourko, Joseph, \& Molloy, Raven. 2015. Regulation and housing supply. Pages 12891337 of: Handbook of Regional and Urban Economics, vol. 5. Elsevier.

Hsieh, Wing, Norman, David, Orsmond, David, et al. . 2012. Supplyside Issues in the Housing Sector. RBA Bulletin, September, 11-19.

Huang, Juan, Shen, Geoffrey Qiping, \& Zheng, Helen Wei. 2015. Is insufficient land supply the root cause of housing shortage? Empirical evidence from Hong Kong. Habitat International, 49, 538 - 546 .

Jeffreys, Pete. 2016 (December). Land banking: What's the story?

Jou, Jyh-Bang, \& Lee, Tan. 2007. Do tighter restrictions on density retard development? The Journal of Real Estate Finance and Economics, 34(2), 225-232.

Kania, Katarzyna. 2014. Premises For Buildng A Land Bank By Developers. Real Estate Management and Valuation, 22(1), 36-43.

Kendall, Ross, \& Tulip, Peter. 2018. The Effect of Zoning on Housing Prices. Research Discussion Paper 2018-03. Reserve Bank of Australia.

Lange, Rutger-Jan, \& Teulings, Coen N. 2018. The option value of vacant land and the optimal timing of city extensions. CEPR Discussion Paper No. DP1284\%.

LeEs, Kirdan. 2018. Quantifying the costs of land use regulation: evidence from New Zealand. New Zealand Economic Papers, May, 1-25.

LendLeASE. 2018. 2018 Annual Report. Tech. rept. Lendlease.

Letwin, Oliver. 2018 (June). Independent Review of Build Out Rates - Annexes. Tech. rept. Ministry of Housing, Communities and Local Government.

Lewis, Sally AnNe. 2017. Reconciling Australian planning, development and housing outcomes. Ph.D. thesis, Faculty of Architecture, Design and Planning.

Markusen, James R, \& Scheffman, David T. 1978. The timing of residential land development: A general equilibrium approach. Journal of Urban Economics, 5(4), 411-424.

Murphy, Alvin. 2018. A dynamic model of housing supply. American Economic Journal: Economic Policy, 10(4), 243-67.

Murray, Cameron. 2019. Marginal and Average Prices of Land Lots Should Not Be Equal: A Critique of Glaeser and Gyourko's Method for Identifying Residential Price Effects of Town Planning Regulations. Available at SSRN 3328308. 
Murray, Cameron K. 2018. Developers pay developer charges. Cities, 74, 1-6.

Muth, Richard F. 1960. The demand for durable goods. University of Chicago Press. Pages 29-96.

NHSC. 2013. 2013 State of Supply Report: Changes in how we live. Tech. rept. National Housing Supply Council.

NSW Government. 2013. White Paper - A New Planning System for NSW. Tech. rept. NSW Government.

PACIOREK, Andrew. 2013. Supply constraints and housing market dynamics. Journal of Urban Economics, 77, 11-26.

PEET. 2011. Annual Report 2011. Tech. rept. PEET.

PEET. 2018. Annual Report 2018. Tech. rept. PEET.

QGSO. 2019. Residential land development activity profiles.

Quigley, John M, \& Raphael, Steven. 2004. Is housing unaffordable? Why isn't it more affordable? Journal of Economic Perspectives, 18(1), 191-214.

Quigley, John M, \& Rosenthal, Larry A. 2005. The effects of land use regulation on the price of housing: What do we know? What can we learn? Cityscape, 69-137.

Schlesinger, LARry. 2018. Stockland selling \$700m Melbourne housing estate The Grove. Australian Financial Review, October.

Shoup, Donald C. 1970. The optimal timing of urban land development. Papers in Regional Science, 25(1), 33-44.

Stover, Mark EDward. 1986. The price elasticity of the supply of single-family detached urban housing. Journal of Urban Economics, 20(3), 331-340.

TAN, Su-Lin. 2016. The free market has failed to provide affordable housing in Sydney and Melbourne. The Australian Financial Review, August.

Thomson, Jimmy. 2018. Developer tricks that could cost an off-the-plan buyer their apartment. Australian Financial Review, August.

Titman, Sheridan. 1985. Urban land prices under uncertainty. The American Economic Review, 75(3), 505-514.

U.S. Federal Housing Finance Agency. 2019 (March). All-Transactions House Price Index for Houston-The Woodlands-Sugar Land, TX (MSA) [ATNHPIUS26420Q]. retrieved from FRED, Federal Reserve Bank of St. Louis.

Verwer, Peter. 2013. Renovating Housing Policy. Public Seminar by Grattan Institute.

White, PAul. 1986. Land availability, land banking and the price of land for housing: A review of recent debates. Land Development Studies, 3(2), 101-111.

Williams, Joseph T. 1991. Real estate development as an option. The Journal of Real Estate Finance and Economics, 4(2), 191-208.

Woodcock, Ian, Dovey, Kim, Wollan, Simon, \& Robertson, Ian. 2011. Speculation and resistance: constraints on compact city policy implementation in Melbourne. Urban policy and research, 29(4), 343-362. 
Zhang, Xiaoling, Bao, Haijun, \& Skitmore, Martin. 2015. The land hoarding and land inspector dilemma in China: An evolutionary game theoretic perspective. Habitat International, 46, 187-195. 


\section{Appendix: The divided housing supply literature}

Table A1: Top group sampled from the real options literature and bottom group from regulation-focussed literature

\begin{tabular}{|c|c|c|c|c|c|c|c|c|c|c|}
\hline & Citations & $\begin{array}{l}\text { Cross- } \\
\text { citations }\end{array}$ & supply & elasticity & $\begin{array}{r}\text { zoning/reg/ } \\
\text { planning }\end{array}$ & $\begin{array}{r}\text { free } \\
\text { market }\end{array}$ & $\begin{array}{r}\text { neo- } \\
\text { classical } \\
\end{array}$ & option & $\begin{array}{r}\text { timing/ } \\
\text { time }\end{array}$ & $\begin{array}{r}\text { delay/ } \\
\text { wait } \\
\end{array}$ \\
\hline Shoup (1970) & 132 & $0(0)$ & 0 & 0 & 5 & 0 & 0 & 0 & 24 & 13 \\
\hline Markussen (1978) & 57 & $0(0)$ & 29 & 7 & 0 & 0 & 0 & 0 & 36 & 0 \\
\hline Titman (1985) & 800 & $1(0)$ & 0 & 0 & 0 & 0 & 0 & 11 & 19 & 7 \\
\hline Williams (1991) & 410 & $2(0)$ & 1 & 0 & 3 & 0 & 0 & 28 & 20 & 0 \\
\hline Capozza \& Li (1994) & 409 & $1(0)$ & 2 & 10 & 1 & 0 & 0 & 43 & 54 & 20 \\
\hline Kanoh \& Murase (1999) & 12 & $1(0)$ & 0 & 1 & 8 & 0 & 0 & 34 & 20 & 2 \\
\hline Cunningham (2007) & 135 & $2(2)$ & 7 & 1 & 31 & 1 & 0 & 56 & 63 & 9 \\
\hline Guthrie (2010) & 44 & $1(4)$ & 28 & 56 & 17 & 0 & 0 & 85 & 36 & 36 \\
\hline Dispasquale (1999) & 330 & $0(0)$ & 102 & 32 & 0 & 0 & 0 & 0 & 23 & 2 \\
\hline Glaeser \& Gyorko $(2003)^{7}$ & 759 & $0(0)$ & 12 & 6 & 72 & 2 & 4 & 0 & 10 & 1 \\
\hline Quigley \& Raphael (2004) & 472 & $1(0)$ & 21 & 14 & 35 & 0 & 0 & 0 & 11 & 0 \\
\hline Quigley \& Rosenthal (2005) & 303 & $2(0)$ & 32 & 14 & 235 & 0 & 0 & 1 & 12 & 8 \\
\hline Glaeser, Gyorko \& Saks (2005a) & 677 & $2(0)$ & 10 & 0 & 28 & 1 & 0 & 1 & 33 & 0 \\
\hline Glaeser, Gyorko \& Saks (2005b) & 544 & $2(0)$ & 29 & 1 & 54 & 5 & 1 & 1 & 15 & 4 \\
\hline Glaeser, Gyorko \& Saks (2005c) & 469 & $3(0)$ & 77 & 9 & 57 & 0 & 0 & 0 & 20 & 1 \\
\hline Glaeser, Gyorko \& Saiz (2008) & 770 & $3(0)$ & 109 & 154 & 3 & 0 & 0 & 1 & 62 & 2 \\
\hline Glaeser \& Ward (2009) & 408 & $2(0)$ & 10 & 11 & 104 & 1 & 0 & 0 & 11 & 1 \\
\hline Kendall \& Tulip (2018) & 6 & $3(0)$ & 38 & 3 & 150 & 0 & 0 & 0 & 20 & 6 \\
\hline Lees (2018) & 2 & $3(0)$ & 37 & 2 & 113 & 0 & 0 & 0 & 19 & 3 \\
\hline
\end{tabular}

Word counts include abstract and text only, not titles or reference lists. Cross-citations are own-group with other-group in parentheses. 